\title{
1. Eastern Mediterranean mobilities after the Arab Spring: transformations over time or sudden change?*
}

\section{Natalia Ribas-Mateos}

\section{INTRODUCTION $^{1}$}

This introductory chapter both presents this book on eastern Mediterranean mobilities and serves as a sort of fragment of a work in progress due to the suddenly changing events in the region. While taking on the challenge of capturing the contemporary moment, the chapter also reflects on the longue durée, the historical background of mobilities in the Mediterranean. In particular, two types of materials are reviewed here: the proceedings of a 2014 conference that covered the topics discussed in this book and the various chapters contained in this very text. ${ }^{2}$ The conference featured debates with more than 20 presentations. This book presents ten of the talks converted from papers into book chapters. While the conference proceedings provide an overview of the debates, the book explores specific issues brought up during them.

Global shifts, configuration, reconfiguration, ${ }^{3}$ change, rupture, regression, reform, revolution and mass protests are all terms often heard when trying to interpret what has happened during and since the 'Arab Spring'. What is generally seen is quite similar to a media report or high-level political science paper - looked at on a regional scale, sub-regional scale or as a particular case study - and is usually nationally framed. This chapter looks at this type of change through a different lens, through thinking about the logics of transformation, even if the issues are still complex at the end; and I am obliged to leave a very wide door open for them in the conclusions. 
First, I emphasize problematization in this context in the consideration of a particular cross-cutting theme: mobilities. ${ }^{4}$ This is a very particular topic that has been perceived as peripheral in post-2011 developments in the Middle East and North Africa (MENA) region, as Beaugrand and Geisser noted in their 2014 Conference talk (2014: 2) apropos protest movements: 'while Arab politics were brought back into the scientific spotlight, refugees, exiles, migrants and their descendants received little attention despite their significant role in the protest movements that toppled dictatorial regimes (in Tunisia and Egypt), contributed to weakening them (Yemen, Bahrain, Syria) or forced them to reform from within (Morocco, Jordan)'.

Secondly, this problematization is constructed by examining a schema that simultaneously either integrates change or permanency. Thus, instead of supporting change or supporting non-change (continuity, immobility, etc.), I will explain how continuity and change are paradoxically interrelated in that they are not only embedded but can be represented in a multiplicity of social relations. This two-fold aspect can be very well related to a globalization analysis, highlighting the complex interplay of continuities and changes, for example, when considering the role of the nation-state (in multiple ways, not only related to mobilities), and how the continuity of its old roles are considered. Thus the Arab States would not be seen as exceptional here but rather in line with trends of change on the lines of neoliberal globalization.

This also applies to the so-called erosion of the state (somewhat like what Sassen described in her 2014 work) when considering the role of territoriality and borders, ${ }^{5}$ new inputs (economic privatization, the importance of agency in migration, etc.), old inputs (colonial borders, the legal conception of who is a guest $t^{6}$ or an alien, using old forms of inclusion-exclusion as well as reinterpreting them, e.g., the regional treatment of foreigners and asylum seekers) and how such inclusion-exclusion dynamics can be read within a debate on conceptions of hospitality and conceptions of conditionality and temporality (as Osseyran 2014, does in her article on the important meaning of giving temporary status to Syrian refugees in Turkey).

Furthermore, to understand this interplay of changes, I mainly focus on the following aspects: (i) the blurring of migration categories; (ii) the spatial challenge of changes vis-à-vis a multi-scalar 
interpretation: regional concentration, the reinforcement of Fortress Europe and the diversification of mobility routes, the selection of border zones as key research areas (including the fact that intensified border violence seems to be a key issue in the post-2011 mapping) and the view of the metropolitan space as a key space of cosmopolitan life (e.g. the metropolitan area of Istanbul); (iii) cross-border circulation (concerning humanitarian aid and humanitarian corridors); and (iv) border clashes, which are posited between state-centred notions (watan/daula, nation and state in Arabic) and postcolonial geopolitical borders and have been particularly impacted by global economic processes and the Arab Spring.

In this last respect, the Arab Spring has not only had an impact on the increase in the already high numbers of refugees (as in the cases of Syria and Yemen, a country which had civil wars prior to 2011) but also on the exit of migrants (especially in the case of Libya, Tunisia and Egypt) and some student migration as part of political activism (as in the case of Tunisia and Egypt vis-à-vis micro-blogging) (Thiollet 2013: 133). This type of impact is also expressed in a transnational politics of belonging. Beaugrand and Geisser's chapter provides some examples: children of economic migrants, Arab intellectuals in exile, youths who came temporarily to complete their studies in the West, illegal residents and businessmen, all calling for the triumph of democracy. This connection between migration and the Arab Spring can also be seen in Europe. For instance, Rohde's (2014) research concerns jihadists in Hamburg, a phenomenon explained on the one hand as part of a youth subculture and on the other as the result of political frustration apropos non-intervention in Syria and a product of the global propaganda ${ }^{7}$ displayed by the Islamic State.

Therefore, there is a need to open new doors to explore the processes of reconfiguration through theoretical, empirical and interdisciplinary research, taking into account the different repositioning of actors in a local, regional and global space. In short, after examining this body of research it is vital to dissect the interscalar interpretation of mobilities after the 2011 upheavals across North Africa and the Middle East through the adoption of a challenging multidisciplinary perspective.

The structure of this work corresponds to the main question regarding where to locate change. The first sections of this chapter set the stage by presenting the debates, issues and concepts 
surrounding the main question of whether or not a qualitative change in post-2011 mobilities can be found. I put forward such a broad question in order to highlight key constituent elements over a large analytical terrain in the eastern Mediterranean. The chapter continues by tracing changes and continuities. This work employs a foundational overview of the existing literature in combination with a revision of the various works introduced here (see the 2014 conference $\operatorname{articles}^{8}$ ).

The argument in this chapter is developed in seven different sections. After the introduction, the first part presents a contextual map of social transformation, where the first section draws attention to the concept of this social transformation. I then look at the general debates around the key question of changes and continuities. After that, I locate place in the general narrative. The fourth section reviews some of the attempts to discuss changing categories. The fifth section, in the second part of the chapter, focuses on the analysis of the forms of continuation in migration patterns. The sixth section does that for the cases of border settings, while the seventh discusses particular forms of humanitarian cross-border circulation. Finally, the last section before the conclusion discusses the case of Istanbul.

\section{THINKING ABOUT TRANSFORMATIONS}

Most of the studies presented in this volume are concerned with specific aspects of cross-border mobility and their impact on particular groups and individuals located in different areas of the eastern Mediterranean after the eruption of the so-called Arab Spring. In this introductory chapter, by contrast, my aim is to step back from concrete and location-based case studies and present some reflections on the general challenges - whether transformations or sudden changes - faced by contemporary mobilities in the eastern Mediterranean in order to stimulate a general discussion.

Therefore, in this section I have opted to engage in an interpretation which uses social transformation processes ${ }^{9}$ as a starting point in order to understand shifting patterns of human mobility as a crucial area of social sciences research. In this way I follow Castles' (2010) suggestion that a central theme for contemporary analysis should be the processes of social transformation in the 
context of reconfigurations ${ }^{10}$ of economic and political relationships in the new global order, and more specifically, in the context of this book, in the eastern Mediterranean. This then implies two central contexts of social transformation, one related to global changes visualizing the links between human mobility and global change and the other related to the impact of the Arab Spring, where cross-border flows are seen as key instruments of change. Nevertheless, taking such change into consideration represents a historical, interdisciplinary and cross-area focus, all embedded in social relations within a multi-scalar setting.

However, some caution is required. These general interpretations are difficult to grasp when attempting a reading that is not only wide in space but also short in time. It is necessary to first think through the historical background in a more minute way, because as Butler (2014: viii) puts it:

the historical context is not just a container for logic; logic cannot be extracted from every context and found to be the same. The context seeps into the forms of neoliberal logic, giving them their rhythms, mechanisms and dynamics. That neoliberalism seeks to destroy the ways that economic relations are embedded in cultural and social life does not mean that the theory of neoliberalism must repeat those gestures, extracting the phenomenon from its historical grounds.

That of course can be extended to the way in which neoliberalism provides a background for the Arab and Turkish upheavals and how it overlaps with issues of mobility.

Secondly, the book takes a close look at short-term events and even micro-examples which provide the opportunity to think about transformations in the belief that it is beneficial to review small examples of upheavals in order to better locate change. If one reviews some forms and origins of revolts in these transformations, it emerges as the weight of a genealogy. This is why I think it is important to capture the nature of the early risers of popular mobilizations to understand the importance of the examples on the ground. This is done for example by determining whether the urban question or the right to the city has been an issue from the start, as was the case with Gezi Park in Istanbul. There are several other cases, such as Leenders and Heydemann's (2012) analysis with special reference to Deraa, where the Syrian uprising began and whence it spread to Homs, Deir Al-Zour and Idlib, showing that we 
can learn from the 'early risers'. For these authors, two key notions in social movements theory (SMT) helped 'trigger mass mobilization among these early risers, in part as a result of demonstrations emanating from Tunisia and Egypt, and in part as a response to the heavy repression unleashed by Syria's security forces in Deraa, particularly between 18 March and the beginning of May 2011' (ibid: 140). Leenders and Heydemann note how surprising it was that the uprising happened in such a provincial agrarian Syrian city as Deraa, which was perceived as largely loyal to the Ba'ath regime and which had benefited from land reform. The urban perception was that it was backward, marginal, conservative and isolated (ibid: 142). This local example reflects the importance of relying on a comprehensive approach by detailing a socio-spatial level of change. To understand such social change is fundamental to understanding how a movement begins and what impact on mobilities it may have, even if there is no space here to go to an in-depth analysis of such a case.

Thirdly, the book takes on more challenges when using generalities, especially when trying to integrate multiple levels of analysis into a single mapping and taking into account all the factors at both global and regional level (Izquierdo and Feliu 2015). In the post-Arab Spring context mobilities are clearly complex, both historically and currently. In an opinion piece, Khalid Koser (2012) discusses how the Arab Spring represents an uneasy mix of optimism and pessimism, extending into the realms of migration and displacement in the region. On the one hand, the pessimist perceives the omnipresence of violence and war, while on the other the direct experience of displacement, combined with regime change based on concerns about dignity, rights, social justice, legitimate governance and representative democracy, should provide an opportunity to strengthen international protection principles at both national and regional levels. Koser further delineates how violence and forced migration also cause social transformation. He underlines how conflict destroys economic resources, undermines traditional ways of life and breaks up communities. Thus logically, forced migration is a factor that deepens underdevelopment, weakens social bonds and reduces the capacity of communities and societies to achieve positive change. Furthermore, a post-conflict situation does not go back to the pre-conflict one. Fully understanding changes requires a global analysis of impacts in locations on 
many levels in order to examine the different aspects of crossborder mobilities as a main site of the observance of a reconfiguration and transnationalism from below. This effort means not only understanding the global, but also searching for new methodologies to grasp such interconnections.

\section{OPENING THE MAIN DEBATES}

This chapter seeks to stimulate a discussion about changes in mobilities. ${ }^{11}$ The ideas presented here are elements of a debate and need to be inserted in a wider general context. This work examines the tangled question of continuity and change from the point of view of the observance of mobility. Studying the diverse changes since the upheavals of January 2011 in Mediterranean mobility is a topic worthy of particular attention. However, extra effort has to be made in order to understand conceptions of continuity and change, which are sometimes found in sharp opposition to each other but which are nevertheless connected and interrelated. Consequently, this chapter brings these conceptions together in dialogue from at least five different angles:

\section{(i) The Use of Categories}

Can we keep using the terms refugee and irregular migrant in the same way as we did in the past? Globalization studies have shown new challenges in blurring ${ }^{12}$ such categories. Agamben (1995) has also problematized the meaning as regarding the differentiation between the classic idea of refugees as victims and that of refugees as rights-bearers from a human rights approach.

\section{(ii) Forms of Continuity}

Authors like de Hass and Sigona (2012: 1) discuss a presumed continuity stating, 'It is rather unlikely that the revolutions will dramatically change long-term migration patterns'. The same processes that have created the conditions for the revolutions are also conducive to emigration and the two phenomena may reinforce each other. In the region, a new generation has grown up, better educated and with wider aspirations and a greater awareness of 
opportunities elsewhere and injustices at home than any previous generation, which suggests a form of continuation in specific cases. ${ }^{13}$

In this respect, Bob-Milliar, ${ }^{14}$ having the Libyan case in mind, asserts that there is no real consensus about the impact of the conflict. While it has been claimed that the fighting led to one of the largest 'migration crises' in modern times, de Haas and Sigona (2012: 1) posit that the revolutions have not 'radically transformed migration patterns in the Mediterranean'. ${ }^{15}$ All the same, the uprising occasioned the involuntary return of citizens from more than 120 countries and sub-Saharan African migrant workers in Libya encountered many problems. Not only were their properties confiscated, but they were also accused of aiding the regime of Muammar Gaddafi as mercenaries (de Hass and Sigona 2012: 7).

\section{(iii) Challenging Borders}

Authors researching EU borders have found a rupture since the Arab Spring, which has led to changes in the regulation parameters of the EU's internal borders (see the examples in the various programmes in Italy after the Tunisian upheaval ${ }^{16}$ and the internal border changes in the context of the 2015 refugee crisis). This challenging of borders raises questions about the countries of departure. Can the slogan 'freedom and dignity' used during the revolts be interpreted as a new indicator of the classic socioeconomic search for freedom of movement found in the southern Mediterranean basin since the late 1980s? Are these new modes of disenfranchisement and new models of resistance as put forward by Salehi (2014)? Can migrant mobilizations from the Arab revolts really be included in this framework? In the specific case of Tunisia, decreasing border controls facilitated the exit from Tunisia at the first moment of the transition. This challenging of borders also addresses an increasing weaponization of borders (Sassen 2014) by reinforcing borders for migrants and asylum seekers, despite major challenges and changes like the claims for freedom in the wake of the Arab Spring and a rhetoric of solidarity.

\section{(iv) Forms of Cross-border Circulation}

Authors working on the Syrian humanitarian crisis show how cross-border circulation enhances a new humanitarian structure 
model, especially concerning the Turkish borders, where actors are seen as behaving quite differently than usual, in particular by connecting with local NGOs.

\section{(v) Re-scaling}

Do cities like Istanbul conform to the kaleidoscope of post-2011 changes and continuities? Do border zones like the Turkish-Syrian border constitute key areas in such a re-scaling? Are these strategic sites for such a change?

\section{'PLACE STILL MATTERS'}

Apart from the debates on mobilities this chapter establishes a connection between globalization and place. Each of the essays in Saskia Sassen's collection on globalization introduces a new type of complexity to the study of the global, confronting questions of space and the fact that both the local and the global are increasingly multi-scalar. In such a theoretical framework this work can (as Sassen does) utilize a progressively urban articulation of global logics and struggles and an articulated frame of the urban space like Istanbul - to make political claims. Therefore, by emphasizing the interplay between global and local phenomena, there is a possibility to examine new forms and conditions such as global cities, transnational communities, transnational families, new mobilities and diasporas and transnational networks of humanitarian response. In this context, the case of Syrian and SyrianPalestinian refugees seems to have a key distinctive presence. It underlines the diasporic space and multiple trajectories that have a particular impact on the eastern Mediterranean (especially concerning Syria's neighbouring countries of Lebanon, Jordan and Turkey) and on a wider scale involving the borders of Fortress Europe (like Greece, Italy and the Moroccan-Spanish borders). It also involves the presence of Syrian refugees in Scandinavian countries, Germany and France (see the cases presented in this book).

Does place still matter? Perhaps yes, but we do need to look for the causes of conflict and displacement in broader patterns of global change before locating the topics of debate. Globalization means the increasing interference of global capital on any particular 
scale, which reveals sharp fragmentation processes together with intensified social inequality and increased human insecurity. A study has been carried out of a very paradigmatic case of such a Mediterranean setting, where cross-border mobility is represented as an axis of interpretation - historically and currently - and where borders are intertwined with mobility filters ${ }^{17}$ in a setting which is today one of the most militarized and heavily patrolled areas in the world, rife with unbalanced social representations. This Mediterranean setting (as an overall area of particular socio-economic crisis, social policies, borders and mobilities) is also particularly challenging because it does away with rigid established area studies in favour of interrelations where the EU, southern Europe, North Africa, the Arab/Berber North Africa, the Arab Middle East, Turkey, the Balkans, etc. are all complex actors in an overarching global mapping.

This Mediterranean setting has implications for at least three main foci: (i) EU enclosures; (ii) border zones; and (iii) the metropolis. ${ }^{18}$ In this setting, Fortress Europe, which was established during the early 1990s, is a basic point of departure. One of the multiple facets of such settings (see the wider context in works like El Río Bravo Mediterráneo: Las regiones fronterizas en la época de la globalización (The Rio Bravo Mediterranean: Border Regions in the time of Globalization)) is the analysis of human casualties (be they on the Mexico-US border or in the Mediterranean basin). Furthermore, the much-cited data from Frontex does not track dead or missing migrants, nor does EUROSUR, the European Border Surveillance System or the International Organisation for Migrations (IOM).

Asylum seekers and immigrants with low levels of education, for example, are often seen as a 'burden' not only for Fortress Europe ${ }^{19}$ but for reception countries in the eastern Mediterranean. Asylum seekers do not fit the category of potential workers and less educated immigrants, who have become undesirable because they depend on market needs. This dichotomous thinking has created a polarization of migration types. Today's borders thus function as a filter, separating the 'wanted' from the 'unwanted' migrants or, as Sassen (1999) has termed it, the 'guests' from the 'aliens'.

In this case many of the questions related to these issues are grounded in a region marked by multilingualism, mobility and strong divisions between the Turkish, Arab, Iranian and Kurdish 
ethnicities and religions (Brandel 2006), as well as by Armenian Greek, Jewish and other minorities. The definition of territories remains problematic as shown by the permanence of the Palestinian-Israeli conflict and national affiliations (the paradigmatic example being the Kurdish situation).

Other authors add how exile, statelessness and refugee crises are the results of state-building in the region (Doraï 2014a: 125). In his case study Doraï particularly focuses on the complexity of understanding mobility, residence rights and protection in the countries where Palestinians look for asylum. After 2011, the PalestinianSyrian situation includes asylum and long-term cross-border mobilities, 'raising the question of refugee status' and secondary mobility. Once they become asylum seekers in other conflicts, their statelessness is evident, as they cannot even seek the protection of their country of origin. As the author notes, this recalls the situation of Palestinians living in Iraq in 2003 and the Palestinians expelled from Libya in 1995. In this context, he ponders the centrality of networks, which can be strong but which seem to be 'depassé' (overcome) in such difficult circumstances. Even if the network can be said to be built by strong community ties and a sense of family, the resources of such ties become scarce in post-war situations.

\section{DISCUSSING CATEGORIES}

One of the most important concepts is the exact meaning of guest. Schwarz (2014) refers to the idea of guests and aliens in a phenomenological description. He distinguishes the alien by the political division of the citizen/non-citizen and the guest by his or her connection to the private realm. He further adds that in private life, guests are usually not expected to work, but to be able to contribute to the everyday life of the host with stories, pictures and, possibly, gifts that reflect an enriching 'otherness' instead of an 'alien-ness'. This idea of the guest also recalls the gastarbeiter (guest worker) regime instituted in Germany in the late 1970s, when the arrivals of young male migrant workers was a planned, directed project separate from family ties, welfare needs or the desires for long-term settlement held by select migrants.

In the case of Turkey the term 'guest' has been widely used to refer to the temporary stay of Syrians in Turkey. According to 
Özden (2014), this 'guest conception' hides the rights and obligations of refugees from the state and reflects embedded ideologies concerning nationalism (vis-à-vis Turkish hospitality and a paternalist approach) and Islamic ideology (vis-à-vis the feeling of Muslim brotherhood). Differences between such guests and other migrants are now present, where the 'Anatolian migrant' has been replaced by others in this 'fabric of otherness' - as noted by Pérouse (2014) - when referring to the 'good' and 'bad' Arab in specific Istanbul neighbourhoods. Such Syrian refugees not only add new questions to previous Syrian migration models, but also raise thoughts about what is new apart from being a 'war refugee' today.

\section{(i) Displaced Migrants}

The Libyan context was not the first time that foreign nationals (e.g. Bangladeshi migrants during the first Gulf War) had been displaced by conflict and violence - although the scale and variety of the different nationalities affected was probably unprecedented and it will not be the last (Koser 2012). Migrant workers from more than 120 countries were displaced during the conflict. ${ }^{20}$

\section{(ii) Forced Migration}

According to Castles (2005), the term 'forced migration' includes not only refugees and asylum seekers, but anyone forced to leave their homes by violence, persecution, development projects, natural disasters or man-made catastrophes. Forced (or involuntary) migration is distinguished in analytical and policy terms from economic (or voluntary) migration. Forced migration includes a number of legal and political categories, all of which involve people who have been forced to flee their homes and seek refuge elsewhere. Popular usage tends to call them all 'refugees', but in legal terms refugees are actually a quite narrow category. The majority of forced migrants flee for reasons not explicitly recognized by international refugee law and many of them are displaced within their own country of origin. Furthermore, as Castles notes, forced migrants are generally divided into the following categories: 


\section{(a) Refugees}

According to the 1951 United Nations Convention Relating to the Status of Refugees, a refugee is a person residing outside his or her country of nationality, who is unable or unwilling to return because of a 'well-founded fear of persecution on account of race, religion, nationality, membership in a particular social group, or political opinion'. The Office of the UN High Commissioner for Refugees (UNHCR) is mandated to oversee the implementation of the 1951 Convention. However, most of the world's forced migrants do not meet the Convention criteria, either because they have not crossed an international border or because they are fleeing war or general human rights violations rather than individual persecution. The 1969 Refugee Convention of the Organization of African Unity (OAU) broadened the refugee definition to include people fleeing war. Many African states follow this practice, but most northern states do not. Instead, in the 1990s the notion of temporary protection for war refugees was introduced, especially for those fleeing the violence in the former Yugoslavia. This means giving protection either for a fixed period (e.g. three years) or for the duration of the conflict. After this, return home is expected and may be enforced.

At regional level, most fundamentally, Jordan, Iraq, Libya and Syria are not signatories of the 1951 Refugee Convention and its 1967 Protocol, although Libya is a signatory to the 1969 OAU Convention. The 1951 Convention is the key legal document defining who is a refugee, their rights and the legal obligations of states. Even in those countries in the region that are signatories, international protection principles have tended to be poorly applied. Neither Egypt nor Tunisia, for example, has a national asylum law. In practice this has meant for decades that Tunisia has denied access to asylum, while in Egypt refugees have effectively been barred from achieving local reintegration (particularly access to employment and services) (Koser 2012). The EU itself did not deliberate a suspension of the Dublin Regulation transfers of Syrian asylum seekers during 2013 and 2014, regardless of the country of destination, and took responsibility for assessing the protection needs of Syrians based on the first country where they lodged an application for asylum. Denaro provides some examples of this type of suspension in Chapter 4. In February 2013 Germany suspended the transfer of two asylum seekers to Italy under the Dublin II 
Regulation and demanded guarantees regarding transfer measures and arrangements for reception.

\section{(b) Persons of concern to the UNHCR}

UNHCR statistics also provide a broader category: 'persons of concern to the UNHCR'. This includes Convention refugees plus all persons for whom the UNHCR takes responsibility at a given time, i.e. those who enjoy protection or assistance services provided by the UNHCR. This includes some asylum seekers, internally displaced persons and returnees. The UNHCR makes a distinction between refugees in camps and outside camps, whether in urban areas or rural settlements, a categorization linked to the implementation of their policies of assistance and eventual protection (Doraï 2014a: 131).

\section{(c) Asylum seekers}

These are people who have crossed an international border in search of protection, but whose claims for refugee status have not yet been decided. Asylum seekers sometimes live in a drawn-out situation of uncertainty and inactivity, since the procedures and appeals may take a number of years. Many countries offer different types of protection, typically full refugee status for those who meet the 1951 Convention criteria, temporary protection for war refugees and humanitarian protection for people not categorized as refugees but who might be endangered by returning. In some countries, asylum seekers are not allowed to work and have to exist on welfare benefits (sometimes at rates lower than those for other welfare claimants). Even though as many as two-thirds of asylum applications are rejected in European countries, many rejected asylum seekers stay on. In some cases, they cannot be deported because their country of origin will not take them back or because they have no passports. Others simply disappear into the informal economy.

\section{(d) Internally displaced persons (IDPs)}

IDPs are defined as "persons who, as a result of persecution, armed conflict or violence, have been forced to abandon their homes and leave their usual place of residence, and who remain within the borders of their own country' (UNHCR 1997: 99). IDPs tend to be poorer and have fewer social connections and are currently far more 
numerous than refugees, yet are often without any effective protection or assistance. There are no international legal instruments or institutions specifically designed to protect IDPs, although they are covered by general human rights conventions. For instance, the Internal Displacement Division (IDD) of the UN Office for the Coordination of Humanitarian Affairs (UN-OCHA) advocates a set of 'Guiding Principles on Internal Displacement'. Syria's internally displaced people are often forgotten in the refugee data.

\section{(e) People-trafficking}

A final form of forced migration is the trafficking of people across international boundaries for purposes of exploitation. The trafficking of women and children for the sex industry occurs all over the world. Women in war zones are forced into sex slavery by combatant forces or sold to international gangs. It is important to distinguish between people-trafficking and people-smuggling. As Nwayn and Ofazoglu (2014) demonstrate, the access that Syrians have to the formal labour market in Turkey shapes their vulnerability to extreme forms of labour exploitation, including trafficking.

\section{FORMS OF CONTINUATION: REPRODUCING MIGRATION PATTERNS}

The previous section reviewed the pertinent categories for discussion. The following section explores two main axes of discussion: the outmoded figure of the guest worker and the continuation of transnational diasporas.

\section{(i) Resurrection of the Guest Worker?}

One could argue that Europe's migration policies are even more misguided and hypocritical than they were after 1973. Europe's failure to face up to the realities of the present situation has produced the great hypocrisy of modern migration policy (one also shared, for instance, by the United States and Japan). Furthermore there is a systematic use of undocumented migrant workers, who are denied many of the rights guaranteed by human rights legislation and labour conventions endorsed by these same countries. The EU and its Member States still seem to be trying to import labour 
but not people - just as the western European countries did 40 years ago (Castles 2006) - but this time with a shrinking labour market. Have migration patterns truly changed considering the models of southern Europe, the Maghreb and the MENA region? Are they perhaps the same migration models but with fewer possibilities, affected by the economic crisis in southern Europe and tighter security border measures?

\section{(ii) The Role of Diasporas}

Some of the literature emphasizes the role of the diaspora in the revolution. For example in the Egyptian case, Hafed notes how the influences on the revolution came from the Egyptian Muslim diaspora in the Arab Gulf through the 'Salafization' of Egypt fuelled by globalization and migration (Hafed 2012: 25). She also mentions the influence of the technological revolution with diaspora networking, especially with the case of the Copts who have influenced internal politics on the subject of human rights. Has the transnational diaspora changed since 2011? To what extent does transnational diaspora formation intersect with post-2011 events in terms of new experiences of displacement and exile, of new tensions in the closing of borders and the contemporary diasporic practices of refugees, which underpin neither the nation-state nor a global framework?

\section{CHANGES: CHALLENGING THE BORDER ${ }^{21}$}

First, historically speaking, borders have always been a controversial issue in the Middle East. However, Doraï indicates that despite the multiplicity of territorial conflicts in the region, few studies have been published on border issues in the Middle East (Dorai 2014a). Nevertheless, edited volumes like the one by Brandel focusing on the nation-state border (2006) make a good contribution to the literature. This text focuses in particular on the case of the Turkish Hatay (analysed by Piccard during the 1970s and by Martin focusing on masculinities at the border in the 1980s), looking at the effects of annexation on the region and its population - in particular Arab minorities - and the handling of the "national questions' in Sanjak. In this case, borders in the Middle East follow 
Yerasimos' territorial formations in the north (Turkish national and military mobilization in reconquering Anatolia) and to the south, in the territories formed by the British occupation. In contrast to the creation of nation-states within the Balkan part of the former Ottoman Empire where national movements prepared the ground for the desired territory, the areas south and east of Turkey either received a different territory from the one they wanted or were unclear about the territory to which they aspired (Brandel 2006).

Secondly, at the contemporary level, in addition to the bibliography related to current 'border shifts' (Ribas-Mateos 2015), there is much literature dealing with the connection between migration and revolution. As Navone (2014) mentions, today there is a multiplicity of actors dealing with borders, and that, apropos his own case study on the Gaza-Israel-Egypt triangle border, the 'border is getting thicker'. In the Sinai case, the crisis that snowballed after the fall of Mohamed Morsi involves a profusion of actors, the 'militarization/weaponization' of borders and an enlargement of the border to the Suez Channel. Therefore this border contrasts with contemporary border studies that explore the key role played by borders as shifting devices, as points or zones producing space-time discontinuities and differential mobility regimes. This case is a real reflection of the linear frontier between Egypt, Israel and the Gaza strip.

Thirdly, there is a further connection between displacement and revolutions. The number of migrants has increased since the Arab Spring uprisings triggered unrest across North Africa and the civil war in Syria began. The IOM recorded the deaths of 3,072 migrants trying to reach Europe in 2014 (as of 29 September). Other data included a ship carrying some 500 migrants, including Syrians, Palestinians and Egyptians and an estimated 100 children, which sank off the coast of Malta. Hundreds of thousands of people have fled Libya since the crisis began in February 2011. As of June 2014, according to the IOM, one million refugees had left the country, with more than 500,000 heading to Tunisia, more than 300,000 to Egypt and 70,000 to Niger (Migreuop 2014). Those figures continued to increase throughout 2015.

The UNHCR has noted the 'growing numbers of Syrians seeking safety in Europe' and expressed its concern 'about severe difficulties these displaced people face during their passage and at borders. This includes the risk of drowning at sea and incidents where 
Syrians have been dangerously hindered in their journeys' (UNHCR 2013: 1). The UNHCR estimates that 6,233 Syrians had arrived in Italy by boat since August 2013 compared with about 350 in all of 2012. In recent years, Syrians became the largest nationality arriving in Italy; in 2013, approximately 25,000 migrants arrived in Italy by boat, of whom 9,805 were Syrian, 8,843 Eritrean, 3,140 Somali, 1,058 from Mali and 879 Afghanis. The Italian Interior Ministry believes that most departed from Libyan territory. The Egyptian government estimates that some 250,000 to 300,000 Syrians resided in Egypt in 2013, of whom more than 122,000 were registered with the UNHCR (UNHCR 2013). As Denaro notes in Chapter 4 , the number of unaccompanied children is also on the rise in these movements. There is an increasing number of unaccompanied children making the voyage ... As the cost of travel can range from US $\$ 2,000-$ US $\$ 5,000$ per person, some families opt to send their children alone or with relatives'. The UNHCR responded thus in 2013:

UNHCR is calling [on the EU and other partners] for a number of measures to prevent further tragedies and increase responsibility sharing. UNHCR called upon states beyond Syria's immediate region to explore concrete and meaningful ways of expressing solidarity, notably with a view to sharing the immense burden and protection responsibilities currently being assumed by the countries neighbouring Syria and its vicinity, such as Egypt. Warning signs in some hosting countries testified to the potentially destabilizing impact of the Syrian refugee influx that aggravated the already severe political, security, and economic repercussions of the Syria conflict. (UNHCR 2013: 2)

Fourthly, another level of border analysis goes back to Fortress Europe, where the architecture of its construction is reflected in data on the recent evolution there. The contrast between the expenses on EU border control and the EU refugee fund is quite extreme in the data from between 2007 and 2013 (see especially the imbalance between the cases of Bulgaria, Greece and Spain $^{22}$ ) (Amnesty International 2014: 9-10). The European Commission Programme on Solidarity and Management of Migration Flows (2007-2013) notes that half of the budget is allocated to the External Borders Fund, while the other half is split between the refugee fund, the integration fund and the return fund (Amnesty International 2014: 25). 


\section{CHANGES: NEW FORMS OF HUMANITARIAN BORDER CIRCULATION}

In the humanitarian context, the role of the UNHCR, under whose mandate refugee protection primarily falls, is fundamental, but many other international organizations play a part. Many intergovernmental agencies are involved, including the World Food Programme (WFP), the United Nations Development Programme (UNDP), the United Nations Children's Fund (UNICEF), the IOM and the International Committee of the Red Cross (ICRC). In addition, hundreds of NGOs also play a key role. These include for instance Save the Children, OXFAM, the International Rescue Committee and Médecins Sans Frontières, as well as local groups and individual citizens. States and their relevant agencies and national humanitarian organizations may also be seen as part of the regime (Castles 2005) in addition to all the NGOs working with the so-called 'Mediterranean crisis' since the first tragic events in Lampedusa.

Nevertheless, these border circulation policies are imbued with contradictions regarding protection-control, expulsion-acceptance, etc., about which an extended body of literature exists. ${ }^{23}$ Campesi (2014) has highlighted the ambiguous dialectic logics between the technocratic ideology of risk management and the recurrent call for emergency rhetoric that characterizes Euro-Mediterranean border control policies, showing how Frontex has ultimately succeeded in capitalizing on the recurring humanitarian policy that violates the fundamental right to flee.

These kinds of border circulation analyses are not only reflections on the idea of trauma, witness and humanitarian action, but also reveal forms of political subjectification where 'the victim is not only a rhetorical figure, he/she also becomes a political subject' (Fassin 2008: 540). Fassin adds that 'humanitarian testimony contributes to forming victim subjectivities to which social agents must make reference, among other things to make a demand for justice heard - that is, precisely, to escape from the logic of compassion' (Fassin 2008: 542).

With regard to other political contradictions at the local level, Ruiz de Elvira (2014a) uses her fieldwork with Syrian refugees in Gaziantep to show how they grapple with a new civil society which 
is, by their own definition, quite apolitical, but through their actions they are really engaging in politics. In a very similar setting, Schmelter (2014) discusses an interesting change from open-border policy to refoulement practices in Lebanon, as well as the change from a no-camp policy to informal tented settlements, the particular framework in which local humanitarian actors work. Her research reveals how local parties hold strong transnational linkages where humanitarian networks operate in a politicized context, leaving little room for questions about social and political rights. Lastly, Michalak (2014) examines humanitarian assistance since 2012 in several specific cases through the prism of an instance of a complex humanitarian corridor like the border city of Gaziantep, where the humanitarian network comprises NGOs based in Syria, NGOs which are diaspora-based and so forth. This is particularly innovative in contrast with other humanitarian crises (e.g. Darfur).

\section{GOING DOWN THE SPATIAL SCALE: LOOKING AT ISTANBUL}

In the Middle East, where today several million refugees and displaced people have concentrated (mainly Palestinians, Syrians, Sudanese, Yemenis and Iraqis), the population is predominantly urban, based in cities such as Cairo, Amman, Beirut and Damascus (Doraï 2014a: 130). This phenomenon contributes to a redrawing of the contours of major cities in the region (ibid: 135). In the case of Turkey, there is also a contemporary conception of the guest refugee. These types of questions related to Syrian refugees as a particular post-2011 community are still part of an ongoing individual research project in a small neighbourhood (the area of Balat in the historical peninsula of Istanbul), which deals with memory, mobilities and mobilization as a way of looking at various local changes.

In this displayed mobility, mapping Turkey seems to play a vital role, following its regional position as a 'central country' in global politics, undertaking a leading role as 'Islamo-democrats'. In this context, Mourenza and Ortega (2014) establish a detailed historical and contemporary mapping of new mobilities in the country. They first go back in history. According to the 26/09/2006 Settlement Act enacted in 1934, only people of Turkish descent and culture could 
migrate and settle in Turkey. Between 1923 and 1997, the Bulgarians were the largest group to settle. Bulgarian migrants were called göçmen (emigrants) by Turkish society and had already received many opportunities from the Turkish state in 1989. They were followed by Bosnian Muslims from the former Yugoslavia (1992-95) and asylum seekers and refugees from Iran, Iraq, Somalia and Afghanistan. From 1988 to 1991, there was a massive influx of Kurdish refugees into Turkey from Iraqi Kurdistan. Today, Turkey has not only opened its borders to Syrian refugees, Iraqis, Libyans and Palestinians, but also to Egyptian exiles and those coming from other countries in the Maghreb. For this reason and with regard to both refugees and new tourists, as already noted, Pérouse (2014) focuses his presentation on 'good' and 'bad' Arabs in the streets of Istanbul since the end of 2012, especially in Tarlabaşı and Taksim Square.

The beginning of all of the issues presented here took place in Istanbul with international as well as Turkish scholars and activists. Most of the talks at the 2014 Conference placed a particular emphasis on the role of Syrian refugees in Turkey, and more specifically Istanbul, due in part to the novelty of the phenomenon as well as to the speed with which Istanbul became the metropolis with the highest number of Syrian refugees, registered and nonregistered. Syrian refugees have, then, become guinea pigs to show how migration management works for countries assuming both transit and destination roles together with their traditional emigration roles, as with the cases of Turkey and Morocco (see Afailal, Chapter 3 in this book).

\section{CONCLUSION}

This chapter offers a brief outline of how change might be applied in a particular area of the world - the eastern Mediterranean. I make no pretence that this sketch can do justice to the complex reality there but I hope I have offered a review of some attempts to stimulate reflection and debate on such change. Is this simply an intersection of events within mobilities or something more consistent? Do we, as observers, challenge new EU scenarios regarding borders and refugees? Do we, as researchers, handle migration policy and border politics issues and humanitarian policies in a 
novel way in such a context? Are all these questions linked to a current and complex analysis of reconfigurations in the region?

In her classic Guests and Aliens (1999), Sassen sought to trace Europe's past immigration histories, highlighting the role of foreigners as rights-bearers. The authors in this book have tried to understand the role of post-2011 mobilities in shaping rights and as a barometer for measuring a shift, looking at the topic in the context of social transformation and how migrant categories, migration patterns and borders and cross-border circulation are the main analytical axes. How is post-2011 change located? At least five angles posit new questions to tackle this inquiry:

\section{(i) Change, Rupture, Continuity?}

How do 'freedom and dignity' slogans translate into migration changes and human right issues? Can migrant mobilizations be traced from the starting point of the Arab revolts? How have migration patterns changed since the 1990s? Is it possible to truly talk about a 'before and after' of mobilities in the aftermath of the Arab Spring?

\section{(ii) Contesting Borders}

Borders, or more exactly, border zones in the region are not only spaces of violence, as shown in Kosmopolous's description (2014) by showing the spectacle of institutional pushbacks and the scenarios represented by the black masks and anti-riot gear worn by Greek border guards, but also spaces of contested conditions between migration networks clashing with a wide range of EU border control mechanisms. This conflict highlights the interplay of multiple factors and actors which reveal an interesting field of globalization, establishing connections between the Arab Spring and borders.

\section{(iii) New Political Identities}

Is there a clear connection between the Arab Spring and the reinforcement of Fortress Europe? Is there a clear connection between the Arab Spring and the demand for freedom of mobility and dignity of migrants? It is possible to discuss a transformation of 
the political identity of refugees and, more particularly, a new claim for political identity in the way that Denaro (2014), Özden (2014) and Ruiz de Elvira (2014a) discuss? Ruiz de Elvira (2014a) argues that policies should be contemplated in a broad sense ${ }^{24}$ and that actors who claim to be apolitical (gheyr siyasi) but are de facto political should be looked at closely, especially in her case study of the politicization of assistance to Syrian refugees, where charitable work can also mean resistance.

\section{(iv) Placing Mobility in the Architecture of Membership}

Is a re-politicization process of migrants as political actors underway? Özden (2014), for instance, criticizes the image of refugees as victims of war (which victimizes and infantilizes them) and defends an image reinforced by their political identity and cultural production, fighting for their visibility and right to the city in Istanbul.

This question leads to considerations of how mobilities interfere with the enclosure of the EU and their architectures of membership (described by Sassen 2014), revealing a grey zone between the powerless and the empowered, especially in metropolitan areas and at European borders - both spaces of persecution. Enclosure has previously been seen as contrary to mobility, but various authors show how agency is constructed by dealing with different deadlocks, impasses and bottlenecks.

Is the possibly outmoded question of the discrimination of the alien coexisting with 'the right to have rights' (see Sassen 2014, Schwarz, Chapter 5 in this book), confirmed by the withdrawal of immigrant rights by national legislatures, still pertinent? In such a membership framework Sassen (2014) asks whether the ideological renationalizing of citizenship can coexist with the Europeanizing of membership and complex transnational identity politics. Are states reinforcing their power in deciding who is in and who is out, as well as the possible designation of the foreigner (alien, guest, citizen, denizen, etc.) and reinforcing their power to decide who comes in and who is pushed back ${ }^{25}$ across the border? Where is the global left then? 


\section{(v) New Circulations}

The Arab Spring's impact on mobilities is clearly characterized by a mixture of flows (Thiollet 2013) and thus it is even more pertinent to refer to mobilities. This is intensified by another impact: the complex context of the humanitarian crisis, which has resulted in complicated cross-border corridors of goods, where international and local NGOs play an important role. This is different to what has usually been seen in other regional crises. In this case, local NGOs have been making a special effort to connect with the outside world.

\section{NOTES}

* I would like to thank Susanne Schmelter and Christoph Schwarz for reading the draft of the chapter. I would also like to thank The Reconfiguration Network for supporting this publishing venture.

1. Since this chapter was written a growing wave of events has occurred in the region: (i) an increase in the number of Syrian refugees (the total number of refugees as of 17 November 2015 was 4,289,792: <data.unch.org/ syrianrefugees $>$, accessed 20 November 2015); (ii) an increase in refugee arrivals via the Mediterranean (836,883 by sea in 2015), 85 per cent coming from the world's top ten refugee-producing countries, 52 per cent of whom are Syrian: <data.unhcr.org/Mediterranean/regional.php>, accessed 8 April 2016; (iii) the opening of the western Balkan routes for refugees; (iv) the emergence of new political changes regarding the so-called EU refugee crisis (e.g. Germany ceasing to apply the Dublin system rules to Syrian refugees); and (v) the impact of terrorism (Paris, 13 September 2015) on the representation of refugees, the suspension of Schengen agreements and the closure of Europe's internal borders.

2. However, the materials overlap to some extent as they occasionally draw on different versions of works by the same authors. In both cases I have been the coordinator.

3. Theorization of the concept of reconfigurations can be also included here. See for example Rohde (2014). His approach to the MENA region focuses in particular on four research fields: history from below (authoritarian rule periods, society and actors, labour conflicts, everyday resistance, etc.), reconfigurations of cultural memory (remembrance, study of the silent), political transformations and transitional justice (legal context and judiciary role in transitions) and transregional entanglements (by including internal and external factors). Drawing on the theoretical resources of transregional comparisons in area studies, Rohde seeks to adopt political-economy perspectives and critical theory into 'critical area studies' in order to help conceptualize the contradictory expressions of current globalization. 
4. By using the term 'mobilities' this work aims to bypass the binary dichotomy of the separated spheres of forced migration (used in classic refugee studies) and volunteer migration (with the importance of the idea of agency and autonomy in such a framework). Furthermore, the book talks about mobilities not only because it acknowledges a paradigm shift (Sheller and Urry 2006) but also because general classic migration categories have become limited in order to encompass an expanded and wide spectrum of contemporary forms of mobilities.

5. Border focus here is mainly understood in a wide relational sense where border processes are connected to and disconnected from both territoriality and sovereignty - meaning tighter control, enhanced security and developing technological surveillance.

6. According to Osseyran (2014), hospitality raises questions of conditionality, alterity, belonging and sovereignty. She articulates this as part of the debate surrounding how migrants, refugees and other mobile people not only arrive, but also how they remain. Debates on hospitality revolve around who gives hospitality, how it is enacted and why it is performed. She also gives this hospitality a sense of temporality, as temporary protection incorporates the idea of duration and connects to a spatial conception (in the case of Syrians in Turkey she refers to the camps, the border zones and to the case of Istanbul). In another context, Schwarz (2014) traces the notion of the gastarbeiter in Germany and translates it to the contemporary situation with Syrian refugees and the lack of 'the right to have rights' (recalling Hannah Arendt in The Origins of Totalitarianism, 1951).

7. Rohde also describes the case of the small northern town of Celle, Germany, which saw clashes between the Yezidi community and Chechen refugees, and between Muslim/non-Muslim refugees in Hamburg, apparently also triggered by events in Syria/Iraq. Furthermore in the case of Berlin and Hamburg, Salehi (2014) describes the situation of sub-Saharan Africans coming from Libya via Lampedusa, who, after having received asylum in Italy, found out that their permits in Germany did not allow them to work.

8. See 'Guest and Aliens. Reconfiguring Mobilities After 2011', Istanbul, December 2014, IFEA and Reconfigurations Network (University of Marburg) hereafter '2014 Conference'.

9. An analysis of the processes of social transformation could provide the basis for a new understanding of the links between human mobility and global change. According to Castles, social transformation (making use of the classic idea of social transformation from Karl Polanyi) can be defined as a fundamental shift in the way society is organized that goes beyond the continual processes of incremental social change that are always at work. This implies a 'step-change' in which all existing social patterns are questioned and many are reconfigured. Social transformations are closely linked to major shifts in dominant economic, political and strategic relationships (Castles 2010: 1576). In this general context, what does mobility have to do with it? Castles tries to look for a contemporary response to such questions. In this respect, he then uses Polanyi's idea of the 'double movement' transported to the modern lens of the concept of agency. Social transformation processes are mediated by local historical and cultural patterns through which people develop varying forms of agency and resistance. These can take the form of religious or nationalist movements, but also of individual or family-level 
livelihood strategies, including rural, urban and international migration (Castles 2010: 1576).

10. I am aware that the term 'reconfiguration' is not commonly used. It has mainly been used to refer to Norbert Elias' conceptual architecture in order to avoid linear, evolutionary thinking about configuration that denotes a dynamic and complex social configuration where its nature is socially built by means of cultural heritage. In this work 'reconfiguration' serves to capture the different dynamics of continuity and change.

11. Beaugrand and Geisser present a context for understanding the role of mobilities in diasporas, migration and exile after 2011, arguing that political upheavals have opened up new theoretical questions that can enrich the already vast literature on migrants and diaspora.

12. This blurring is a continuation of the problems encountered when thinking about what 'forced migration' means (see also note 4 on the term 'mobilities' bypassing the binary dichotomy of the separated spheres of forced migration), which is normally a loss of control in terms of one's situation. Even if we differentiate between migrants and refugees, the blurring of categories is always there. In this context, Kunz's classic typology (1981: 42), which emphasizes the lived experiences of refugees, is pertinent: (i) the majority (driven by opposition to political and social events), (ii) others who relate to events connected to the condition of refugee (driven by discrimination) and the (iii) self-alienated (driven by individual and personal reasons due to ideology and their alienation in the receiving country).

13. Notwithstanding, while they see some continuity, they also observe the existence of new interactions: 'Sea and landing on the island of Lampedusa, and the numerous Egyptian émigrés and university students returning to Cairo to join the protests in Tahrir Square are a few examples of the ways in which human mobility has intersected the events in North Africa' (de Hass and Sigona 2012: 1).

14. According to Bob-Milliar (2012: 23), migration governance or management was intertwined with the popular uprisings in the Maghreb. However, the root causes of the revolutions that swept across the region in 2011 were said to be linked to rulers denying political and economic rights. The demands for political and economic inclusion from Tunisia resonated with citizens in Egypt, Libya and beyond. The revolutions re-ignited discussions about migration governance in the Global North. However, southern governments were concerned about the loss of remittances, increased youth unemployment and regional instability caused by returning fighters. The ousting of the Gaddafi regime triggered a 'migration crisis' in the region. Libya was home to an estimated 1.5 million migrant workers and its descent into chaos saw an exodus from the country that overwhelmed aid agencies in the initial stages.

15. IOM statements are statements from the field as the IOM is an important player in migration management. International agencies dealing with flight and migration issues like IOM and UNHCR speak of larger crises, as Susanne Schmelter has noted in Chapter 9 of this book. A deeper analysis however reveals that migration patterns have been reinforced but not radically transformed in the region.

16. One of the most obvious examples is the case of the Saint-Ludovic border where Tunisians were sent back to Italy using readmissions agreements. Different camps were organized in Italy to assist migrants during April 2011: 
first aid and acceptance centres, reception centres for asylum seekers, shelters and identification and expulsion centres. The Italian government issued a decree granting six-month residence permits for humanitarian reasons. A second example is the closing of French internal borders in Ventimiglia and the containment of African migrants.

17. See Ribas-Mateos 2015.

18. It also poses a geographical problem regarding its delimitation. The case of the Arab Maghreb-Middle East region is pertinent in this context as well. However, in this case the cartography is established by the eastern Mediterranean, i.e. the countries located geographically to the east of the sea: Greece, Albania, Turkey, Cyprus, the Republic of Macedonia, Egypt, Israel/Palestine, Jordan, Lebanon and Syria. What counts, however, is how processes here are particularly connected to a wider Mediterranean setting (in relation to contemporary transformations).

19. As Kosmopoulous (2014) shows, at some EU borders, migrants and refugees are denied access to asylum procedures and pushed back into neighbouring countries, often in ways that put them at grave risk. They are treated poorly by border guards and coastguards and left stranded in neighbouring countries where there are serious human rights concerns. With safer routes to Europe being closed off through increased securitization, and in the absence of legal channels into the EU, migrants and refugees are attempting ever more hazardous routes. Thousands have died on the journey since 2000; many more are missing and feared dead, especially around the EU border where Bulgaria and Greece meet Turkey, one of the main routes used by Syrian refugees seeking safety in the EU. In a similar context, in Chapter 4 Denaro analyses the reopening of the Egyptian route to Italy as well as the Italian reception system concerning Syrian and Palestinian refugees and unaccompanied Egyptian minors to Italy.

20. Koser mentions that there are indications that certain states and the international community have been spurred into action by the events in Libya to begin to plan responses to future displacements of foreign workers. Some of those evacuated from Libya originated in South and Southeast Asia - over 36,000 from Bangladesh alone. It was noted, for example, that different ministries had managed the evacuation of Bangladeshi migrant workers after the first Gulf War and the Libya crisis, resulting in little institutional memory. During the Libyan crisis, the Philippines also created an Overseas Preparedness and Response Team within the Office of the President, tasked with formulating and periodically reviewing contingency plans in times of crises affecting Filipinos overseas (Koser 2012).

21. In addition to the general theoretical immersion into the border that I have done on other occasions, I refer here in particular to the references to border theory by Vila, Barth, Van Gennep, De Geneva, Khosravi, Mezzadra and Neilson, which frame Navone's fieldwork in the Sinai regarding the idea of crossing and reinforcing borders, the establishment of 'border device' filters, selections for rejection, slowing down, waiting and expulsions.

22. For Spain the allocation of refugee and external border funds (2007-13) was divided as follows: $€ 9,342,834.50$ for the Refugee Fund and €289,394,768.35 for the External Border Fund. These figures very clearly reflect the type of policies implemented. 
23. I have already pointed out this contradictory nature on other occasions (see Ribas-Mateos 2014: 56), the contradiction between policies of control and policies of social integration, between social policies and immigration policies, between discriminatory policies and policies of tolerance, between child protection policies and immigration laws, between policies of compassion and criminalization policies, etc.

24. She reviews the literature in order to understand such a concept. This includes, for instance, Asef Bayat, Life as Politics: How Ordinary People Change the Middle East. Stanford: Stanford University Press. 2010. He particularly focuses on the diverse ways in which ordinary people, the subaltern - the urban dispossessed, Muslim women, globalizing youth, and other urban grass roots - strive to affect the contours of change in their societies by refusing to exit from the social and political stage controlled by authoritarian states, moral authority and neoliberal economies, discovering and generating new spaces within which they can voice their dissent and assert their presence for bettering their lives.

25. Push-backs occur when people are pushed back to the country they are trying to leave - or in some cases into the high seas - shortly after they cross the border, without an opportunity to challenge their forced return. Push-backs usually involve a group of people (migrants or refugees). The deportation of a group of people without looking at each case individually is a collective expulsion and is prohibited under international law (Amnesty International 2014: 20). Refoulement is the forcible return of someone to a country where they would be at risk of serious human rights violations. International law prohibits the transfer of anyone to a place where their lives or freedoms are at risk -this is known as the principle of non-refoulement. It has reached the status of customary international law, meaning it is binding upon all states, including those who have not ratified the relevant international instruments. Some non-state actors are also bound by the principle of non-refoulement, for example those exercising authority on behalf of a group or states, such as Frontex (Amnesty International 2014: 13), which became operational in 2005, and EUROSUR, the European Border Surveillance System, which became operational in December 2013.

\section{REFERENCES}

Afailal, H. (2014), Euro-Mediterranean relations in the field of migration management: contrasting Morocco and Turkey as case studies. Paper presented at the International Conference 'Guests and Aliens. Re-configuring New Mobilities After 2011'. IFEA Istanbul, 9-10 December.

Agamben. G. (1995), Homo Sacer: Il potere sovrano e la nuda vita. Torino: Einaudi.

Bayat, A. (2013), Life as Politics: How Ordinary People Change the Middle East. 2nd edition. Stanford: Stanford University Press.

Beaugrand, C. and Geisser, V. (2014), Thinking the role of Diasporas, migrants and exiles in the Arab Revolutions and Political Transitions. 
Paper presented at the International Conference 'Guests and Aliens. Re-configuring New Mobilities After 2011'. IFEA Istanbul, 9-10 December 2014.

Bob-Milliar, G.M. (2012), Rescuing Migrants in Libya: The Political Economy of State Responses to Migration Crises - The Case of Ghana, Working Paper, no. 16 (DIIS, Dec. 2012)

Brandell, I. (ed.) (2006), 'Introduction'. In Inga Brandell, State Frontiers: Borders and Boundaries in the Middle East. London: I.B. Tauris, 1-33.

Bredeloup, S. and Pliez, O. (2011), The Libyan Migration Corridor. Florence: European University Institute/Robert.

Butler, J. (2014), 'Foreword'. In Umut Özkirimli, The making of a protest movement in Turkey \# occupyzgezi. New York: Palgrave Pivot Macmillan, vii-xvi.

Campesi, G. (2014), 'Frontex, the Euro-Mediterranean Border and the Paradoxes of Humanitarian Rhetoric (November 5, 2014)'. South East European Journal of Political Science, II(3): 126-134; Criminal Justice, Borders and Citizenship Research Paper No. 2519410

Castles S. (2005), Draft for special issue of Asian and Pacific Migration Journal (APMJ) based on December 2004 Jakarta Workshop, 26 September 2005.

Castles, S. (2006), 'Guest workers in Europe: A Resurrection?'. International Migration Review, 40: 741-766.

Castles, S. (2010), 'Understanding Global Migration: A Social Transformation Perspective'. Journal of Ethnic and Migration Studies, 36(10): $1565-1586$.

Chatty, D. (2010), 'Epilogue'. In Dawn Chatty and Bill Finlayson (eds), Dispossession and Displacement: Forced Migration in the Middle East and North Africa. Oxford: Oxford University Press, 21.

Chatty, D. (2010), Displacement and Dispossession in the Modern Middle East. Cambridge: Cambridge University Press.

Denaro, C. (2012), La crisi del 'Modello Lampedusa'. Studio di caso sulle politiche di gestione dei flussi migratori proveniente da Nord Africa. Anno Accademico 2011/2012. Facolta di Scienze Poliche, Sociologia, Comunicazione. Tesi di Laurea.

Denaro, C. (2014), The reconfiguration of the Mediterranean migratory routes after the war in Syria. Focus on the 'Egyptian route' to Italy. Paper presented at the International Conference 'Guests and Aliens. Re-configuring New Mobilities After 2011'. IFEA Istanbul, 9-10 December.

Doraï, K. (2014a), 'State, Migration and Borders' Fabric in the Middle East', Frontera Norte, 26 (special issue 3): 119-139.

Doraï, K. (2014b), The role of transnational networks and cross-border circulation in Palestinian migration in situation of conflict. Paper 
presented at the International Conference 'Guests and Aliens. Re-configuring New Mobilities After 2011'. IFEA Istanbul, 9-10 December.

Dromgold, M. (2014) Understanding migration management and its impacts on Syrian refugees in Turkey. Paper presented at the International Conference 'Guests and Aliens. Re-configuring New Mobilities After 2011'. IFEA Istanbul, 9-10 December.

Fassin, D. (2008), 'The humanitarian politics of testimony: Subjectification through trauma in the Israeli-Palestinian Conflict'. Cultural Anthropology, 23: 531-558.

Goodhand, J. (2011), 'War, peace, and the places in between: why borderlands are central'. In M. Pugh, N. Cooper and M. Turner (eds), Whose Peace? Critical Perspectives on the Political Economy of Peacebuilding. London: Palgrave Macmillan.

de Haas, H. and Sigona, N. (2012), 'Migration and revolution', Forced Migration Review 39 (July), available at: www.fmreview.org/northafrica/dehaas-sigona.

Hafed, H. (2012), 'The Arab Spring and Migration in Egypt, One Year On: Impacts, Perceptions and Attitudes'. Cairo Studies on Migration and Refugees. The Center for Refugees and Migration Studies, American University in Cairo. Paper no. 5. October.

Hall, A. (2012), Border Watch. Cultures of Immigration, Detention and Control. Pluto Press: London.

Human Rights Watch (2011), 'We've never seen such horror: crimes against humanity by Syrian security forces'. 1 June.

Izquierdo, F. and Feliu, L. (2015), La movilización social y los regímenes de poder en la Primavera Árabe. Una propuesta de pauta de análisis. Paper presented at the XXVIII Encuentro del FIMAM. Universidad Pablo Olavide, Sevilla, 12 June.

Koser, K. (2012), 'Migration, Displacement and the Arab Spring: Prospects for the Next Year'. 22 March, available at http:// www.brookings.edu/research/opinions/2012/07/01-displacement-arabspring-koser.

Kosmopoulos, G. (2014), The human cost of Fortress Europe: human rights violations against migrants and refugees at Europés borders. (Amnesty International Greece video conference). Paper presented at the International Conference 'Guests and Aliens. Re-configuring New Mobilities After 2011'. IFEA Istanbul, 9-10 December.

Kunz, E.F. (1981), 'Exile and Resettlement: Refugee Theory'. International Migration Review, 15(1/2), 42-51.

Leenders, R. and Heydemann, S. (2012), 'Popular Mobilization in Syria: Opportunity and Threat, and the Social Networks of the Early Risers'. Mediterranean Politics, 17(2), 139-159.

Marcus, G. (2009), 'Introduction: Notes toward an Ethnographic Memoir of Supervising. Graduate Research through Anthropology's Decades of 
Transformation'. In James Faubion and George Marcus (eds), Fieldwork is not What it Used to Be. Ithaca: Cornell University Press, pp. 1-36.

Michalak, H. (2014), The Syrian crisis: Transborder flows and the restructuration of humanitarian routes. Paper presented at the International Conference 'Guests and Aliens. Re-configuring New Mobilities After 2011'. IFEA Istanbul, 9-10 December.

Mourenza, A. and Ortega, I. (2014), Syrian refugees: analysing the political discourse and its media impact. Paper presented at the International Conference 'Guests and Aliens. Re-configuring New Mobilities After 2011'. IFEA Istanbul, 9-10 December.

Navone, L. (2014), The field before the battle. Palestinian mobilities and the Gaza-Israel-Egypt triangular border before (and after) 2011. Paper presented at the International Conference 'Guests and Aliens. Re-configuring New Mobilities After 2011'. IFEA Istanbul, 9-10 December.

Nawyn, S. and Pantic Oflazoglu, V. (2014), Turkey's Human Trafficking Policies and Vulnerability of Syrian Refugees to Labor Exploitation. Paper presented at the International Conference 'Guests and Aliens. Re-configuring New Mobilities After 2011'. IFEA Istanbul, 9-10 December.

Özden, Ş. (2013), Syrian Refugees in Turkey. Migration Policy Centre (MPC) Research Report 2013/05.

Özden, Ş. (2014), Guests or Refugees. Transformations in Turkish border towns post-2011. Paper presented at the International Conference 'Guests and Aliens. Re-configuring New Mobilities After 2011'. IFEA Istanbul, 9-10 December.

Pérouse, J.F. (2014), The 'good' and the 'bad' Arabs in Istanbul streets since the end of 2012. Paper presented at the International Conference 'Guests and Aliens. Re-configuring New Mobilities After 2011'. IFEA Istanbul, 9-10 December.

Ribas-Mateos, N. (2005), The Mediterranean in the Age of Globalization. Migration, Welfare and Borders. New Brunswick: Transaction Publishers.

Ribas-Mateos, N. (2014), 'Introducción. Montando una pequeña caja de herramientas para las movilidades adolescentes'. In N. Ribas-Mateos and S. Laíz, Movilidades Adolescentes. Elementos teóricos emergentes en la ruta entre Maruecos y España. Barcelona: Edicions Bellaterra, 25-59.

Ribas-Mateos, N. (2015), Border Shifts. New Mobilities from Europe and Beyond. Frontiers of Globalization series. New York: Palgrave Macmillan.

Rohde, A. (2014), Mapping Reconfigurations. Paper presented at the International Conference 'Guests and Aliens. Re-configuring New Mobilities After 2011'. IFEA Istanbul, 9-10 December. 
Ruiz de Elvira, L. (2014a), 'Asociaciones de beneficencia y política desde una perspectiva comparada: los casos de Siria y Túnez'. Encuentro FIMAM, Toledo 12 and 13 June.

Ruiz de Elvira, L. (2014b), Syrian associations in the Turkish-Syrian border region and in Lebanon. Preliminary notes from a comparative perspective. Paper presented at the International Conference 'Guests and Aliens. Re-configuring New Mobilities After 2011'. IFEA Istanbul, 9-10 December.

Salehi, M. (2014), Leaving Libya: The Re-Configuration of Mobility in Times of War and Complexity. Paper presented at the International Conference 'Guests and Aliens. Re-configuring New Mobilities After 2011'. IFEA Istanbul, 9-10 December.

Sassen, S. (1999), Guests and Aliens. New York: New York Press.

Sassen, S. (2014), Migrants or Expelled? Beyond the 20th century migration modes (video conference). Paper presented at the International Conference 'Guests and Aliens. Re-configuring New Mobilities After 2011'. IFEA Istanbul, 9-10 December.

Schmelter, S. (2014), Setting negotiations of humanitarian power into context: Anthropological perspectives on the governance of the Syrian refugee crisis in Lebanon. Paper presented at the International Conference 'Guests and Aliens. Re-configuring New Mobilities After 2011'. IFEA Istanbul, 9-10 December.

Scholte, J.A. (1993), 'International Relations of Social Change'. Buckingham/Philadelphia: Open University Press.

Schwarz, C.H. (2014), Refugees from Syria as 'guests' and aliens in Germany. Paper presented at the International Conference 'Guests and Aliens. Re-configuring New Mobilities After 2011'. IFEA Istanbul, 9-10 December.

Sheller M. and Urry J. (2006), 'The new mobilities paradigm', Environment and Planning A38(2): 207-226.

Thiollet, H. (2014), 'Migrations, exils et printemps arabes', Afrique du Nord Moyen-Orient. La double recomposition. Sous la direction de Frederic Charillon et Alain Dieckhoff, 133-245.

Zolberg, A., Suhrke, A. and Aguayo, S. (1989), Escape from Violence: Conflict and the Refugee Crisis in the Developing World. New York: Oxford University Press.

\section{Web References}

The Migrants Files: https://euobserver.com/investigations/123682 Migreeurope: http://www.migreurop.org/article2001.html?lang=fr UNHCR: http://www.unhcr.org/print/526114299.html 